\title{
成層せん断流の乱流構造
}

\section{STRUCTURE OF TURBULENT VELOCITY AND BUOYANCY FLUCTUATIONS IN STRATIFIED TURBULENT SHEAR FLOW}

\author{
室田 明*・中辻啓二**
}

By Akira MUROTA and Keiji NAKATSUJI

\begin{abstract}
The effects of buoyancy on turbulence structure of a buoyant surface jet are investigated. Velocities and buoyancy fluctuations are simultaneously measured, and their statistic quantities are examined. Distributions of turbulence quantities are strongly affected by buoyancy. Their variations against the shear layer Richardson number can be explained in terms of the production terms in their transport equations. As the buoyancy effects increase, turbulence structure and buoyancy fluctuation balance change from a jet-like regime to a stratified flow-like one. This transition is well related with the large-scale coherent structure's dynamics peculiar to the turbulent shear flows. The buoyancy results in not only reduction of turbulence intensities but also diminution of turbulence scales.
\end{abstract}

\section{1. 緒言}

温排水の環境水への排出あるいは河川水の海域への放 流により形成される成層せん断流は, 初期運動量流束に 加えて温度あるいは密度の非均一に原因して生起する現 象である.この流れには浮力が重要な役割を果たしてい る. 浮力効果が現われて, 流れの成層安定度が増すと, 運動量や熱・物質の鉛直方向乱流輸送が著しく低下する 亡同時に, 流れ場の特性や乱流構造も強く変形を受ける.

このような成層流場における乱流構造や乱流輸送機構 を解明する目的で, 乱流統計量や乱流輸送係数の変化を 局所的安定度を示す指標を用いて普遍的に表現しようと

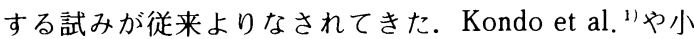
森ら ${ }^{2)}$ の研究では勾配型リチャードソン数を, Ellison ${ }^{3)}$, Townsend $^{4)}$ や Gartrell ${ }^{5)}$ はフラックスリチャードソン数 を指標として, 乱流諸量の定量的把握を試みている.ま た，理論的にも次元解析に基づく相似理論の Monin-Obukhov ${ }^{6}$ から, 乱流応力 - 熱流束の輸送方程 式に基づく乱流モデル (Launder ${ }^{7)}, Y$ (amada ${ }^{8}$ 等) に至 るまで多岐にわたっている。しかしながら，それらは大

* 正会員 工博 大阪大学教授 工学部土木工学科 ( ₹565 吹田市山田丘 2-1)

** 正会員 工修 大阪大学講師 工学部土木工学科 (同上)
気境界層や海洋流を研究対象としており, 流速や温度の 鉛直方向分布が主流方向にあまり変化しないことから， plane-homogeneity が近似的に成立している2).

これに対して, 本研究で対象とする成層せん断流は, その上下を自由水表面と成層内部境界面とに囲まれてお り，周囲環境水の連行を伴う流れである.つまり, 乱流 せん断応力は乱流域を鉛直下方に拡大するように働くの に対して, 浮力効果は内部境界面の拡がりを抑制する働 きを成すと考えてよい. したがって，乱流統計量が勾配 型リチャードソン数等局所的な安定度で統一的に表現さ れるとは言い難く, 流れや乱流構造の流下方向変化を含 めた形で乱流輸送機構を考える必要がある.

著者らは表層密度噴流に発達する大規模な組織的渦構

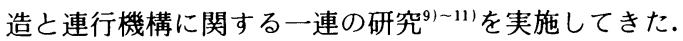
その結果, 連行率 $V_{e} / U_{s}$ とせん断層リチャードソン数 $R i_{h}$ との関係は, 図-1に示すように, 組織構造が連行 に支配的な役割を果たすせん断流卓越領域と, 成層化の ために組織構造が崩壊して連行の減少する浮力支配領域 とに分類されることが判明した。両者の境界值は $R i_{h} \fallingdotseq$ 0.12 であり, 初期安定理論の観点から分散波と非分散 波とに分離される限界值 $0.08 \sim 0.15^{12)}$ に対応している. 運動量流束と浮力流束とを有して表層放流された水束は 初期段階ではせん断効果の卓越した噴流形態を呈する 


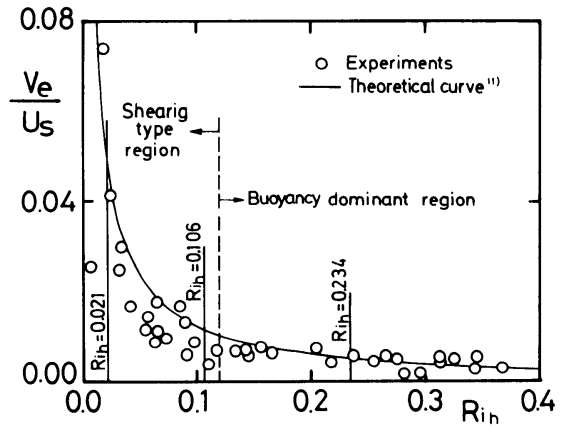

図一1連行率と成居度との関係

が，浮力効果が勝り始めると，放流水束はやがて成層流 的形態に移行する. せん断層りチャードソン数の推移か らみれば $R i_{h} \fallingdotseq 0$ から $R i_{h} \rightarrow 0\left(10^{\circ}\right)$ へと変化するこ とになり，図一1に照らせば，流下とともに周囲環境水 の連行能力が急激に低下することを意味している。

そこで, 本研究では, 表層密度噴流の乱流構造に及ぼ す浮力効果を解明するために，図一1に示したせん断層 リチャードソン数の異なる断面で流速二方向成分と浮力 変動の同時測定を行った. 平均流速・浮力分布, 乱れ強 さの分布, レイノルズ応力や乱流浮力流束の分布, 乱れ エネルギーや浮力変動の生成と消散, 確率密度分布, ス ペクトル特性等乱れの統計量について検討し, 浮力効果 の増大に伴う, 表層密度噴流の乱流構造の推移を明らか にする.

\section{2. 実験}

\section{（1）実験装置}

実験は幅 $0.15 \mathrm{~m}$ ，高さ $0.5 \mathrm{~m}$ の断面を有する長さ $6.0 \mathrm{~m}$ の両面アクリル製水路を用いて行った．水路床勾 配は水平であり,下流堰高は自由に変えることができる. 開水路への供給水系統は淡水と塩水の二系列から構成さ れている．淡水系統の流れはまずヘッドタンクを通り一 定の水頭で流量制御弁，フロート式流量計を通って，開 水路入口に設けた放流口模型に入る．模型端にはステン レス屑が入れられており，また金網で整流されたのちに， 放流口（助走区間 $0.55 \mathrm{~m}$, 設置高 $0.4 \mathrm{~m}$ ） 加表層放 流される．開水路には所定濃度の塩水があらかじめ補給 されており，また淡水の表層放流と同時に連行量に見合
うだけの塩水が塩水系統のヘッドタンクから開水路の下 層へ微調整しながら供給される.

\section{（2）実験条件}

有限長水路で定常な表層密度噴流を作るためには，淡 水流量, 塩水供給量ならびに下流側堰高を各実験に対し て適切に設定する必要がある．それらの值は予備実験を 繰り返し試行錯誤ののちに定めたが，その方法は文献 9）に詳細に示してあるので参照されたい.

実験は浮力効果の影響を抽出できるように塩水濃度を 3 種類変えて行った．各実験に際して放流口流速および 水深が $U_{0} \doteqdot 25 \mathrm{~cm} / \mathrm{s}, H_{0} \doteqdot 1.8 \mathrm{~cm}$ になるように下流側 堰高を変化させて調整した．実験条件は表一1に示すと おりである． $\varepsilon_{0}$ は放流口での相対密度差 $\varepsilon_{0}=\left(\rho_{a}-\rho_{0}\right) / \rho_{a}$ (ここに, $\rho_{0}, \rho_{a}$ は淡水放流水および塩水の密度), $F d_{0}=U_{0} / \sqrt{\varepsilon_{0} \cdot g H_{0}}$ は放流口密度フルード数である．ま た，成層度の非常に大きい実験 Run 4 を比較のために 追加した。

測定断面として，噴流でいうところの流れの確立領域 を選び，放流口から $80 \mathrm{~cm}$ 離れた流下位置 $\left(x / H_{0} \doteqdot 45\right)$ で測定した．表中の $U_{s}, B_{s}\left(=\left(\rho_{a}-\rho_{s}\right) / \rho_{a} \cdot g ; \rho_{s}\right.$ は水 表面での密度, $g$ は重力加速度）は各測定断面における 水表面での平均流速および平均浮力を，また $H$ は勾配 型リチャードソン数 $R i=(g / \rho)(d \rho / d z) /(d U / d z)^{2}$ の急 変点で定義される内部境界面の水深を示す. $R i_{h}$ はせん 断層りチャードソン数であり，流速分布の最大勾配厚 $h$ $=U_{s} /(-\partial U / \partial z)_{\max }$ を用いて $R i_{h}=B_{s} \cdot h / U_{s}^{2}$ で定義さ れる，成層度を示すパラメーターである．各測定断面に おける $R i_{h}$ の值は図一1にプロットして示されている. 同図より，Run 1 はせん断流卓越領域に, Run 3，4 は 浮力支配領域に属し，Run 2 は両領域の遷移段階である ことがわかる.

\section{（3）測定方法}

流下 $(x)$ 方向と鉛直 $(z)$ 方向流速成分 $u, v$ は二 成分熱膜流速計（KANOMAX，21-1312）を用い，ま た塩分濃度は直径 $0.6 \mathrm{~mm}$ の白金線プローブを作製して 電導度式塩分濃度計により測定した．可視観測から流れ が二次元性を保持していることが確かめられたので，両 プローブを横方向に $1.2 \mathrm{~cm}$ 離して設置した. 計測時の 両プローブ間の相互干渉や後流の影響は認められなかっ た。これらの計器からの電圧出力は R-210 型デー夕収

表一1 実釦条件

\begin{tabular}{c|c|c|c|c|c|c|c|c|c}
\hline Run & $U_{0}\left(\frac{\mathrm{cm}}{\mathrm{s}}\right)$ & $H_{0}(\mathrm{~cm})$ & $\varepsilon_{0}$ & $F d_{0}$ & $x / H_{0}$ & $U_{*}\left(\frac{\mathrm{cm}}{\mathrm{s}}\right)$ & $B_{s}\left(\frac{\mathrm{cm}}{\mathrm{s}^{2}}\right)$ & $H(\mathrm{~cm})$ & $R i_{h}$ \\
\hline 1 & 27.0 & 1.86 & 0.0013 & 17.54 & 43.0 & 15.0 & 0.74 & 8.85 & 0.021 \\
2 & 23.5 & 2.03 & 0.0050 & 7.45 & 39.4 & 15.0 & 3.28 & 7.20 & 0.106 \\
3 & 25.5 & 1.60 & 0.0100 & 6.44 & 50.0 & 12.7 & 6.55 & 6.50 & 0.234 \\
4 & 10.5 & 2.15 & 0.0100 & 2.29 & 41.9 & 5.0 & 9.68 & 5.50 & 1.011 \\
\hline
\end{tabular}


録装置 (TEAC 製) でアナログ量としていったん収録し， DR-2000 型デジタルレコーダー (TEAC 製) で $\mathrm{AD}$ 変 換したのちに, 大型電子計算機 ACOS 77/900 で処理し た.

測定は各測定断面で鉛直方向に 20〜30 点で行い，測 定時間は約 40 秒, サンプリング周波数は $200 \mathrm{~Hz}$ である. 塩分濃度は較正曲線を用いて密度 $\rho$ に変換したのちに, $b \equiv g \cdot\left(\rho_{a}-\rho\right) / \rho_{a}$ で定義される浮力 $b$ で表現される.な お, 座標系は放流口水表面を原点に選び, 流下方向に正, 鉛直下方に正とする.

\section{（4）データ解析のための解析的背景}

均質流体の噴流の特徴は, 乱流域が流れ方向に増加す ると同時に, 流速も流速変動の程度もともに減少してゆ くことである. それゆえ, 平均流速や乱れ変動量に対す る分布の相似性が長さ尺度と速度尺度だけを変えること により自己保存的に保たれる．噴出流体と周囲流体との 密度が異なる密度噴流の場合には, 浮力が有効に働いて 運動量や物質の乱流輸送現象に支配的な役割を果たす。

特に, 運動量流束の作用方向亡重力 - 浮力の作用方向亡 が異なる場合には分布形の自己保存性は崩れることにな る.このような表層密度噴流場では相似性に基づいた積 分型表現の理論展開が困難になり，乱流輸送方程式に基 づく動力学的な解釈が必要となる.

動力学的な側面から均質噴流を眺めた場合, 乱流エネ ルギーの発生源は平均流エネルギーに限定され, 対流輸 送や拡散輸送の貢献が比較的大きく，自己保存性を满た すように乱流エネルギーを輸送する，ところが，密度変 動を伴う場合には浮力効果の度合が各位置によりさまざ まであるために, 流れ場の局所的安定度によって乱流エ ネルギーが密度場のポテンシャルエネルギーに変換され たり，また対流輸送や拡散輸送が抑圧されたりする.

図一2 は各乱れ変動および各乱流流束とその生成項之 の関係を概略的に示したものである．図中の実線の矢印 は勾配型生成項であり，たとえば， $-\overline{u v} \cdot \partial U / \partial z$ の うにせん断応力と平均流速場の勾配との積の形で乱流工
ネルギーを生成する.これに対して, 破線の矢印は浮力 に関与する直接型の生成項である。均質流体の場合には 破線で井んだ範囲だけでエネルギー収支を考えるのに対 して, 非均質流体の場合には各種乱流流束も連成した形 で貢献しており, 非常に複雑な現象になっていることが 同図からも想像できよう.

\section{3. 実験結果とその考察}

\section{（1）乱流諸是の分布}

a) 平均流速分布亡平均浮力分布

図一3 は時間平均流速 $U / U_{s}$ と平均浮力 $B / B_{s}$ の鉛直 方向分布を示す．縦軸は水表面から内部境界面までの距 離 $H$ で無次元表示した鉛直方向位置 $z / H$ を示す. 界 面の位置は後述する勾配型リチャードソン数の鉛直方向 変化 (図一13参照), ならびに浮力変動の歪度および流 速変動の等方性度の鉛直方向分布から総合的に決定し た. 表一1に示されるように，放流口密度フルード数 $F d_{0}$ の小さいほど, つまり浮力が慣性力に勝っている ほど, 成層化が有効に働いて内部境界面 $H$ は小さくなっ ている.

平均流速および浮力分布は成層度の弱いRun 1 では よく類似しており，鉛直下方に凹な形をしている．均質 噴流の慣用的表現である半値半幅で水深を無次元表示し た場合には，この分布はガウス形となり，噴流型の自己 相似な流れである. 成層度が増すに伴って, 平均浮力分 布は少し膨らみ始めて凸な分布形となり，成層流でみら れる $\tanh$ 型に遷移してゆく。これに対して, 平均流速 分布はRun 3 においても山な分布形を呈している. 平 均浮力分布の遷移は, $R i_{h}>0.12$ の流れにおいて鉛直下 方からの周囲流体の連行が極端に減少するという図一1 の結果を反映しているものと考えられる. 強安定成層の Run 4 の平均浮力分布には鋭い勾配を有した明瞭な内部 境界面が発達しているのが認められる.

b) 乱れ強度の分布

図-4 は流速変動および浮力変動の r. m. s. 值 $u^{\prime}, b^{\prime}$

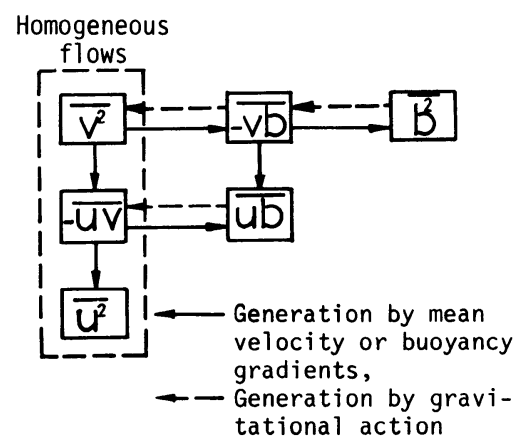

図一2 乱流輸送方程式の関連図
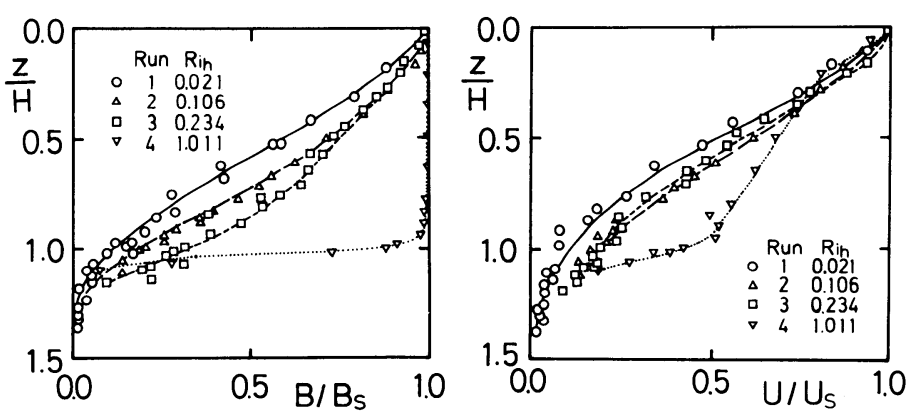

図一3 平均流速と平均浮力の鉛直方向分布 

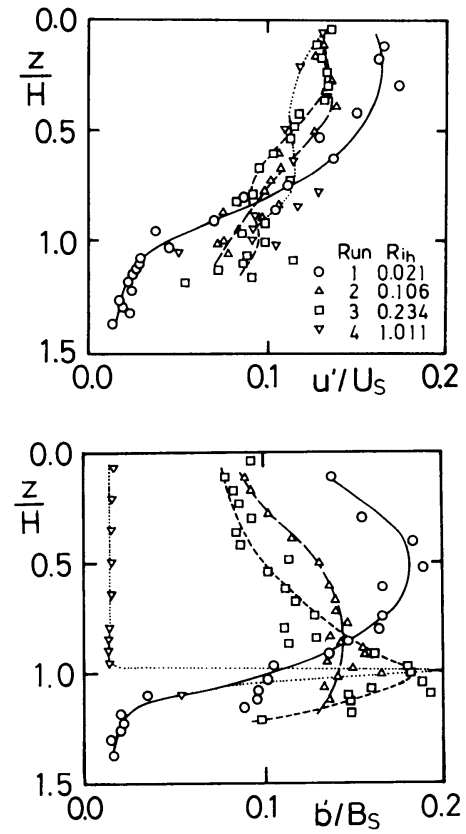

図一4 乱れ強度 $u^{\prime}$ と $b^{\prime}$ の鉛直方向分布

の鉛直方向分布を示す．乱れ強度の分布は平均量分布に 増して浮力効果の影響をより強く受けている.すなわち, $R i_{h}$ の大きいほ亡゙, $z / H<0.6$ での乱れ強度 $u^{\prime}$ と $b^{\prime}$ は 小さくなる傾向を示す.

Run 1 の $u^{\prime} / U_{s}$ の分布形は $z / H=0.25$ 付近で最大值 を示したのちに, 水深の増加とともに一様に減少するの に対して，他の Runでは鉛直方向にそれほど減少しな い.また， $z / H=1.0$ に近くなると，Ri $i_{h}$ の大きいほよ゙ $u^{\prime} / U_{s}$ の值が大きくなり,$z / H<0.6$ の傾向とは逆にな る.

浮力効果の影響は $b^{\prime} / B_{s}$ の分布に顕著に認められる. Run 1 の噴流型自己相似流れでは $b^{\prime} / B_{s}$ の分布形は $u^{\prime} / U_{s}$ のそれと同様の傾向を示すが, Run 3 では $b^{\prime} / B_{s}$ は逆に鉛直方向に一様に増大して $z / H=1.0$ で最大と なる特異な分布となる。強安定成層の Run 4 では $b^{\prime} / B_{s}$ は $z / H \doteqdot 1.0$ で急増大する．乱れ強度の分布は それぞれの輸送方程式中の生成項と直接的に関連してい る.これについてはのちほど議論する.

c) レイノルズ応力と乱流浮力流束の分布

図一5 はレイノルズ応力 $-\overline{u v}$ と鉛直方向乱流浮力流 束 $-\overline{v b}$ の鉛直方向分布を示す. $\overline{u v} / U_{s}^{2}$ の分布形は $R i_{h}$ の値により多少変形するものの, Run 4 を除いて一 様に減少するのに対して, $\overline{v b} / U_{s} B_{s}$ の分布形は $R i_{h}$ に 対して際立った違いを示す。すなわち，Run 1 の成層度 の弱い場合には, $\overline{v b} / U_{s} B_{s}$ の値は $\overline{u v} / U_{s}^{2}$ のそれと比 較して小さいものの, その分布形は $\overline{u v} / U_{s}^{2}$ と同様に
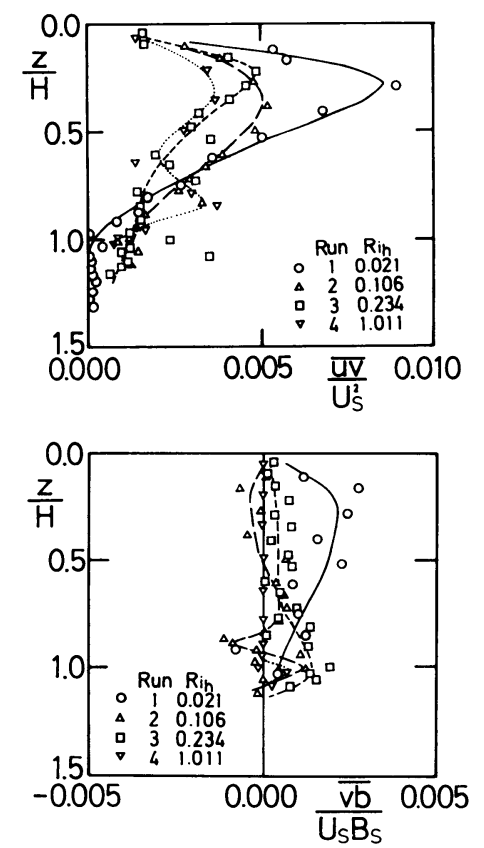

図一5 レイノルズ応力と乱流浮力流束の分布

$z / H=0.3$ 付近で最大値を示し, $z / H$ の増加とともに 一様に減少する。噴流形態から成層流形態への遷移段階 にあるRun 2 になると, $\overline{v b} / U_{s} B_{s}$ の鉛直方向分布は正 負の符号をとる微弱な値となる。ささらに成層度の増した Run 3 では, $\overline{v b} / U_{s} B_{s}$ の值は再び正值となり，今度は 鉛直下方に一様に増大する．同様の傾向が $v-b$ 変動間 の相関係数 $R_{v b}$ にも現われている. Run 2 では $z / H$ の ほとんどの領域で $R_{v b} \fallingdotseq 0.0$ であって, $v$ - $b$ 変動間の相 関はほとんど認められない特異な变動を呈している。

乱れ変動 $\overline{u^{2}}$ と $\overline{b^{2}}$ の輸送方程式中の生成項はそれぞれ 乱流流束之平均流速あるいは平均浮力の鉛直方向勾配と の積, $-\overline{u v} \cdot \partial U / \partial z$ と $-\overline{v b} \cdot \partial B / \partial z$ で表わされる. 図一 4 にみられる $z / H>0.6$ での $u^{\prime}$ と $b^{\prime}$ の増加は図一 5 と図一3の鉛直方向分布と対比することにより理解で きる.

さて, $\overline{u v}$ および $\overline{v b}$ の輸送方程式は

$\frac{D(\overline{u v})}{D t}=-\overline{v^{2}} \frac{\partial U}{\partial z}+\overline{u b}-2 \nu \frac{\overline{\partial u}}{\partial x_{k}} \cdot \frac{\partial v}{\partial x_{k}}+[$ 拡散項 $]$

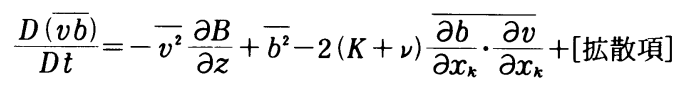

であり，右辺第 1 項は勾配型生成項を，第 2 項は浮力項 を，第 3 項は粘性消散項を表わす．これらの項すべてを 推算することはできないが，生成項と浮力項は評価でき る. 


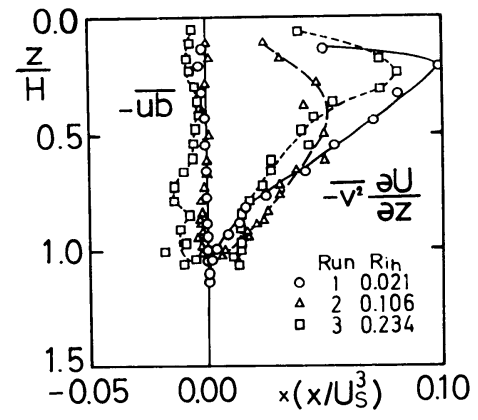

図一 $\overline{u v}$ の生成項と浮力項の分布

図一6，7に示すように，生成項の分布形状は $u v$ あ るいは $\overline{v b}$ の分布形と酷似しており, 生成項が $\overline{u v} や$ $\overline{v b}$ に大きな貢献を果たしているのがわかる，両生成項 には鉛直方台流速変動 $v^{2}$ のネルギーが共通して介在 しており，基本的には図一3に示した平均流速と平均浮 力の分布形状の凹凸の違いが$-\overline{v^{2}} \cdot \partial B / \partial z$ 分布形の違いをもたらしていることが わかる. その結果, $R i_{h}$ に対する $\overline{u v}$ と $\overline{v b}$ の分布形の 変化が著しく異なる.

$\overline{u v}$ の輸送方程式では浮力項の貢献は生成項と比較し て小さい。これに対して， $\overline{v b}$ では成層度の強い流れに なるほど浮力項は大きな負の貢献をするようになり，た とえばRun 2 では $\overline{v b}$ の符号の変化と相関係数 $R_{v b}$ の娍 少をもたらす。特に, Run 3 では $z / H>0.5$ の水深で 負の浮力項が正の生成項を凌駕している.これは $\overline{v b}$ が 全水深で正值となる図一5の結果とは矛盾しており, Run 3 の流れでは評価し得なかった対流項と乱流ならび に圧力拡散項が特異な挙動を呈しているものと予想され る.

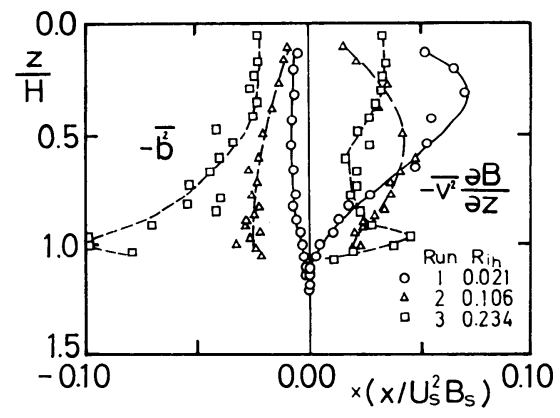

図--7 $\overline{v b}$ の生成項と浮力項の分布

（2）乱流エネルギー収支と浮力变動収支

二次元成層流に対する乱流エネルギー $-\overline{q^{2}}=\overline{\left(u^{2}\right.}+$ $\left.2 \overline{v^{2}}\right) / 2$ の収支式は近似的に次式で与えられる。ただし， $\overline{v^{2}} \fallingdotseq \overline{w^{2}}$ を仮定している.

$$
\begin{aligned}
& -U \cdot \underbrace{\frac{\partial \overline{q^{2}}}{\partial x}-V}_{\text {対流項 }} \cdot \frac{\partial \overline{q^{2}}}{\partial z}-\underbrace{\overline{u v} \frac{\partial U}{\partial z}}_{\text {せん断による生成項 }} \underbrace{-\overline{v b}}_{\text {浮力による生成項 }} \\
& \underbrace{-\frac{\partial}{\partial z}\left\{\overline{v q^{2}}+\overline{v \frac{p}{\rho}}\right\}}_{\text {㹡散項 }} \underbrace{-\varepsilon}_{\text {消散項 }}=0
\end{aligned}
$$

式（3）の消散項は慣性領域の波数に対して成立する $P_{u}(k)=c_{1} \cdot \varepsilon^{2 / 3} \cdot k^{-5 / 3}$ を用いて流下方向流速変動のパ ワースペクトル $P_{u}(k)$ より評価した。係数 $c_{1}$ は 0.5 を 用いた．流下方向対流項 $-U \cdot \partial \overline{q^{2}} / \partial x$ 之圧力相関項 一 $\partial(\overline{v \cdot p / \rho}) / \partial z$ を除いた項は測定值から推算できる. 式（3）の各項を $x / U_{s}^{3}$ で無次元化した分布をせん断 流卓越領域（Run 1) と浮力支配領域（Run 3) に対し て図一8に示す。

生成項は成層度の増大とともに小さくなり, 半値半幅

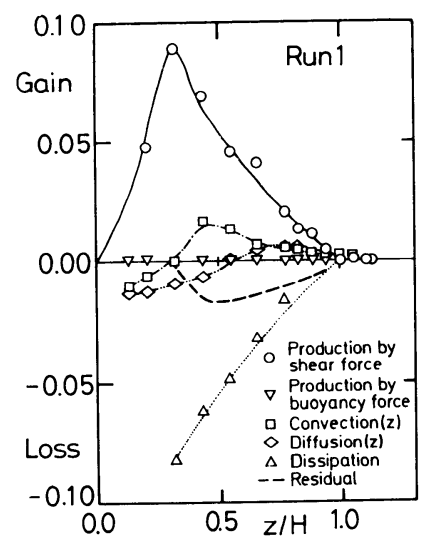

(a) $R i_{h}=0.021$ の場合

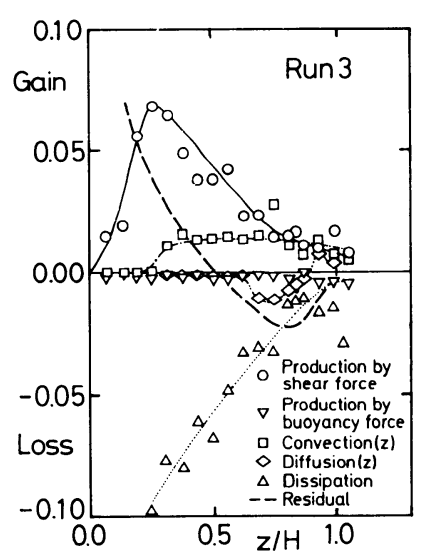

(b) $R i_{h}=0.234$ の場合

図一8 乱流エネルギー収支 
$H_{0.5}$ を用いた慣用的無次元表示である $-\overline{u v} \cdot \partial U / \partial z$ $\cdot H_{0.5} / U_{s}^{3}$ で表わすと, その最大值はRun 1 で 0.005 , Run 3 で 0.003 となる. 均質噴流における実験值 0.014 $\sim 0.017^{(3)-15)}$ と比較して，その值は小さく約 $1 / 3 \sim 1 / 5$ 程度である。

浮力項はRun 1 ではほとんよ゙の水深で0であり，工 ネルギー収支には貢献しないのに対して，Run 3 では損 失側にあり，わずかながらも乱流エネルギーを抜きとる 方向に働く.

乱流拡散項 $-\partial\left(\overline{v q^{2}}\right) / \partial z$ は成層度により異なる. Run 1 ではエネルギー生成の領域 $(z / H<0.55)$ で損失, それ以外では所得であるのに対して, Run 3 では噴流外 縁部 $(0.6<z / H<1.0)$ で損失となる分布を示す. し かもその值は両 Run ともに均質噴流 ${ }^{14)}$ と比較して小さ い. 浮力による鉛直方向流体運動の抑制の影響が現われ ているものと推量される．乱流エネルギーの鉛直方向乱 流流束 $\overline{v q^{2}}$ はRun 1 では $z / H$ のほとんどの領域で正で あり，せん断により生成された乱流エネルギーが鉛直下 方に運ばれる. Run 3 では $z / H \doteqdot 0.8$ で $\overline{v q^{2}}=0.0$ とな る凹部が $\overline{v q^{2}}$ の分布に現われており，このことが上記 の乱流拡散項の違いをもたらすものと考えられる.

粘性による消散項は水表面 $(z / H=0.0)$ に近づくに つれて大きな負の值を示すようになる，それは生成項と 本実験では考慮し得なかった残余の項の和とつり合って いる.

図中の太い破線は式（3）の残余であり，圧力相関項 と流下方向対流項亡の和を表わす. 水表面近く $(z / H$ <0.2）では水表面の振動が消散項の推算に誤差をもた らすので, 破線を示していない. 破線の分布はRun 1 とRun 3 では類似の傾向を示しており, 特に $z / H<$ 0.3 ではその值は他項と比較して非常に大きな值となっ
ている. 均質噴流では平均量および変動量の分布の相似 性の仮定のもとに対流項を推算することが可能となり, その結果, 対流項と圧力相関項のエネルギー収支に占め る割合が大きく，かつ場所による変化が著しいという報 告がある．密度噴流においても同様の傾向があると予想 されるが，今回の測定ではその詳細はわからない.

次に, 浮力変動 $\overline{b^{2}}$ の収支を考える. $\overline{b^{2}}$ の収支式は式 (3) 亡同様に次式で近似的に与えられる.

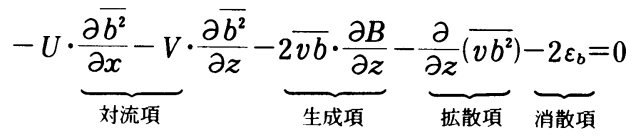

消散項は式（3）の例と同様に浮力変動のパワースペク トル $P_{b}(k)=c_{2} \cdot \varepsilon_{b} \cdot \varepsilon^{-1 / 3} \cdot k^{-5 / 3}\left(こ こ に, c_{2}=0.72^{16)}\right)$ より算出した. $x / U_{s} \cdot B_{s}^{2}$ で無次元表示した式 $(4)$ の 各項の分布を図一-9に示す.

図中に太い実線で示す対流項は, 測定値から推定でき ない流下方向対流項を含んでいるため, 式（4）の残余 として求めた. 対流項の分布はRun 1 とRun 3 で類似 な形をしており, その值は水表面近くで大きく, 水深と ともに急激に娍少して,$z / H \doteqdot 1.0$ 近くで負值となる傾 向を示す.つまり, 水表面近くで大量の浮力変動 $\overline{b^{2}}$ の 供給を対流により受ける. 対流項の断面積分值が 0 でな いことから,この $\overline{b^{2}}$ の大半は上流側から供給されるこ とになる．これは均質噴流のエネルギ一収支にみられる 対流項と類似の傾向を示しており，おそらく図一8のエ ネルギー収支においても同様の分布を呈するものと期待 される。

そこで，鉛直方向対流項（図中の $\square$ 印）を測定値から 求め, 対流項との差, つまり流下方向対流項を示したの が図中の太い破線である. $V>0$ で $\overline{b^{2}}$ の鉛直下方への

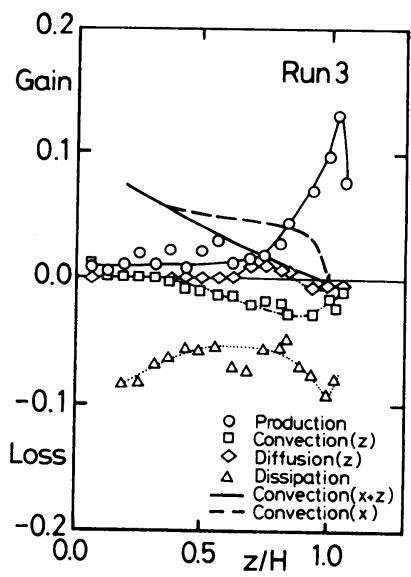

(b) $R i_{h}=0.234$ の場合 
移流に貢献するが, $\overline{b^{2}}$ の鈆直方向分布が Run 1 と Run 3 とでは異なる (図一4参照) ために, $-V \cdot \partial \overline{b^{2}} / \partial z$ の 分布は両者で全く違った傾向を示す.その結果, $-U \cdot \partial \overline{b^{2}} / \partial x$ の分布も著しく異なる. Run 1 では $\overline{b^{2}}$ の 供給が水表面近くで局所的にみられるのに対して，Run 3 ではほとんどの水深 $(z / H<0.85)$ にわたって上流側 から一样に $\overline{b^{2}}$ が供給される。この事実は噴流の拡がり が成層度により抑制され，流動形態が噴流から弱安定の 成層流に移行することから判断して納得できることであ る.

Run 1 では浮力変動 $\overline{b^{2}}$ の生成項は乱流エネルギー $\overline{q^{2}}$ ほどに明瞭なピークをもたないものの, ほとんどの水深 で所得側にあり, $\overline{b^{2}}$ は $z / H>0.65$ で噴流外縁部へ拡散 されているのがわかる.消散項は $\overline{q^{2}}$ の粘性消散と同じ 傾向にある. その值は水表面近くで大きく, 水梁の増加 とともに急激に減少してゆく.

これに対して, Run 3 では $\overline{b^{2}}$ の生成は $z / H=1.0$ の 直上に限定され, しかも $z / H>0.6$ の水深では $\overline{b^{2}}$ を鉛 直上方に乱流拡散する $\left(\overline{v b^{2}}<0\right)$ ように乱流拡散項が 貢献する。 また，消散項は水深方向にほぼ一定の值を示 し, 流下方向対流項と平衡状態を保っているのがわかる.

以上より, $R i_{h}=0.234$ の浮力効果が勝り始めた Run 3 においては, 乱流エネルギー収支は噴流形態の乱流構 造を保持し続けるのに対して, 浮力変動 $\overline{b^{2}}$ は噴流形態 とは著しく異なった収支関係にあることがわかる。つま り, 乱流エネルギーの輸送と浮力変動に代表されるスカ ラ一量輸送の機構は平均流による対流輸送を除いて $R i_{h}$ $=0.021$ と 0.234 とでは本質的に異なる.

この差異の直接的な原因はレイノルズ応力 $-\overline{u v}$ と鉛 直方向乱流浮力流束 $-\overline{v b}$ の分布の違いにあるが, 前項 で述べたよにその根源は平均流速 $U$ と平均浮力 $B$ の 鉛直方向分布の相違, ひいては周囲流体を連行するか否 かに依存する.

\section{（3）乱流構造}

a) 確率密度分布

確率密度分布の変化を定量化する因子として歪度 $S$ と尖度 $F$ とがあり, $S$ と $F$ は確率密度の 3 次および 4 次モーメントであり, $u$ 変動を例に示せば,

$$
S_{u}=\frac{\overline{u^{3}}}{u^{\prime 3}}, F_{u}=\frac{\overline{u^{4}}}{u^{\prime 4}}
$$

で定義される. 図一10に $u$ 変動と $b$ 变動に対する歪度 と尖度の鉛直方向分布をせん断層リチャードソン数 $R i_{h}$ をパラメーターに示す．正規分布の場合の䄳度と尖度は それぞれ $S=0.0, F=3.0$ であり, 図中に破線で表示 する.

Run 1,2 では $z / H=1.0$ に近づくにつれて $u$ 変動之 $b$ 変動の歪度と尖度はともに正規分布から大きくずれる
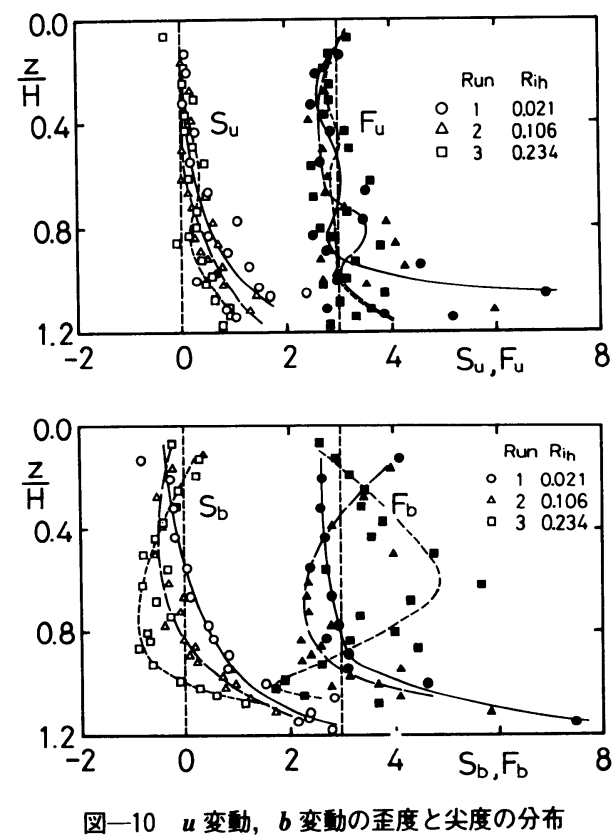

傾向にある. 尖度 $F$ は大振幅変動の度合を表わすこと から, 測定時間内で大振幅変動が現われる時間の割合, すなわち間欠因子 $\gamma$ と $\gamma=3.0 / F$ という関係 ${ }^{17)}$ で結び つけることができる.このことから $z / H=1.0$ 近傍の 流速変動や浮力変動はきわめて間欠的であり, 大振幅変 動がスパイク状に生起していることがわかる.

これに対して, Run 3 では浮力変動の尖度 $F_{b}$ の最大 值は $z / H \doteqdot 0.6$ で現われ, 水深とともに減少する. また, 流速変動にも間欠性はあまり認められない.

b）スペクトル分布および特性渦のスケール

浮力効果の流体運動への影響を評価するために, ここ ではある波数をもつ変動成分が乱れ変動全体にどの程度 の寄与をしているかを調べる. 浮力効果の最も現われや すい流速変動 $v$ を選び, ARM 法によりパワースペクト ル $P_{v}(k)$ を求めた．波数範囲 $(k, k+\Delta k)$ に含まれ る寄与分を $P_{v}(k) \cdot \Delta k$ とすれば, 平均エネルギー(分散) $\overline{v^{2}}$ は次式で表わされる.

$$
\overline{v^{2}}=\int_{0}^{\infty} P_{v}(k) d k=\int_{0}^{\infty} k \cdot P_{v}(k) d(\ln k)
$$

図一11 は $z / H \doteqdot 0.85$ で得られたRun 1,3 の対数ス ペクトル $k \cdot P_{v}(k)$ を示す. 曲線と横軸に囲まれた面積 は平均エネルギー $\overline{v^{2}}$ を示している. 同図より，浮力効 果の強い Run 3 では平均エネルギー $\overline{v^{2}}$ も小さく, かつ 波数範囲が全体的に高波数側に移行しているのがわか る. Run 1 では $k=0.6$ で卓越したピークを呈しており， この波数成分の平均エネルギーに対する貢献が最も大き い.これを周期に換算すると約 3.1 秒となり, 前項で述 


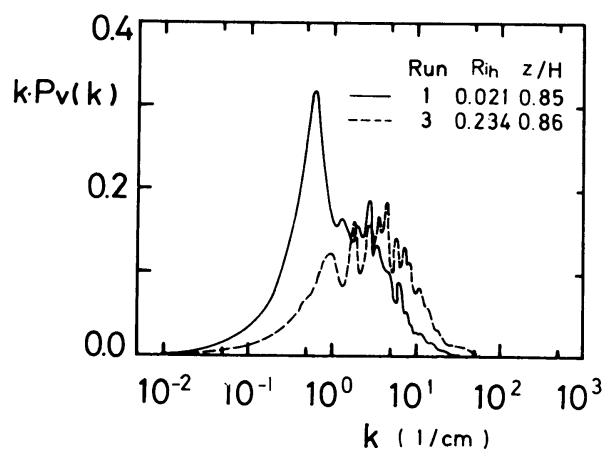

図一11 v 变動の対数スペクトル $(z / H \doteqdot 0.85)$

ベた大振幅変動が時系列に間欠的に出現する周期とよく 一致している，つまり，成層せん断流では浮力効果は低 波数の大スケール乱れ変動を抑圧し，結果として高波数 領域のエネルギーを増大させる役割を果たしているもの と考えられる.このことは, 浮力は加速度であり, 小ス ケール乱れよりも大スケール乱れに及ぼす影響が大きい ことからも納得できる.

そこで, Run 1, 3 の各水深 $z / H$ でのパワースペク トル $P_{v}(k)$ の形状の変化を把握するために, エネルギ一 の $10 ， 20 ， 50 ， 80,90 \%$ に相当する波数 $k$ の分布を $H$ で無次元化して示したのが図一12である.

Run 1 では $50 ， 80 ， 90 \%$ に相当する等エネルギー波 数 $k H$ は $0.5<z / H<0.85$ でいったん減少してから, 内部境界面 $(z / H=1.0)$ 近傍で急激に増加するのに対 して, Run 3 の $k H$ は $z / H>0.5$ の範井で水深ととも に一様に増大する傾向にある。たとえば，Run 3 の $50 \%$ 等エネルギー波数を例にとれば， $z / H=0.55$ では $k H=9$ であったのが, $z / H=1.02$ では $k H=25$ と高波 数側に極端に移行している. 内部境界面 $H$ は Run 1 と Run 3 ではおのおの $8.85 \mathrm{~cm}, 6.5 \mathrm{~cm}$ であり, 波数ある いは周波数に換算したとき, 両者の差は同図以上の差と なる，つまり，浮力支配領域に属する Run 3 では，浮 力による成層化が乱れの変動スケールを減少させて, 流

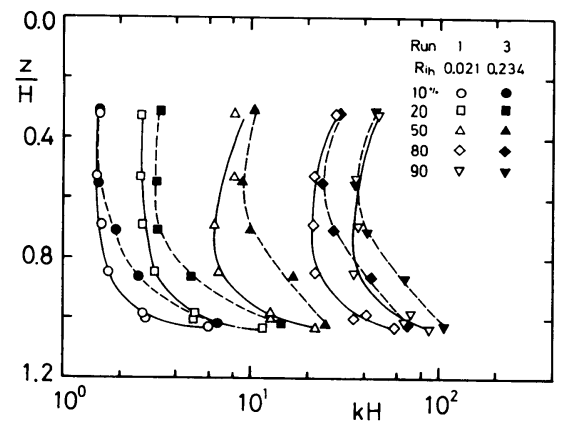

図一12 等エネルギー波数 $k$ の分布
体の鉛直方向運動を抑圧する役割を果たしていることが わかる。

c）内部境界面の挙動特性

鉛直方向の乱流輸送を検討するとき，内部境界面がよ゙ の程度の成層状態にあるかを知ることが重要となる。一 般に, 内部境界面の安定度は勾配型リチャードソン数 $R i=-(\partial B / \partial z) /(\partial U / \partial z)^{2}$ で論じられる. $R i$ は浮力の なす仕事量とせん断による乱流エネルギ一の発生量との 比である。

テイラーの理論 ${ }^{18)}$ によれば， $R i \geqq 1 / 4$ のとき層流は常 に安定である.しかし，乱流の場合にはもう少し大きな 值 $(R i \geqq 1.0)$ になって初めて, 乱れは減衰する.

図一13 は $R i$ の鉛直方向分布を示す. Run 1 では $R i$ の値は小さく, 鉛直方向にほとんど変化しない. $z / H$ $\div 4.7$ になると $R i$ は増加し始める. Run 2,3 では $R i$ は鉛直方向に一様に増加する傾向にある．特に, $z / H$ $\fallingdotseq 3.5$ から $R i$ は急激に増加し, それぞれ $z / H_{0}=3.5$, 4.0 で最大值となる. この水深位置で浮力変動の丕度の 符号が変わり，かつ流速変動間の非等方性度が増大する ことから, この水深を内部境界面 $(z=H)$ と定義できる. 本論文では鉛直方向距離 $z$ の規準化にこの $H$ を採用し ている. 各 Run の最大值は順に 0.20, 0.72,1.29 である. Run 3 においては $R i$ の值が判定条件 $R i=1.0$ を越える ことより，乱れは減衰するものと予想される。これは不 安定擾乱の分散性に基づく $R i_{h}$ を指標とした分類と非 常によく対応している．このことから，大規模，汃組 織的な乱流構造の崩壊する $R i_{h}>0.12$ の浮力支配領域 では, 内部境界面は局所的にも安定していることがわか る.

安定成層流場で共存する乱流と内部波とを分類する方 法として, Stewart ${ }^{19)}$ は鉛直方向流速変動 $v$ とスカラ一 量である浮力変動 $b$ 間のコヒーレンスと位相差の関係 の検討を提案している. 内部波の場合には $v$ と $b$ のコ ヒーレンスは大きくなり，かつ位相差は土 $\pi / 2$ に近くな

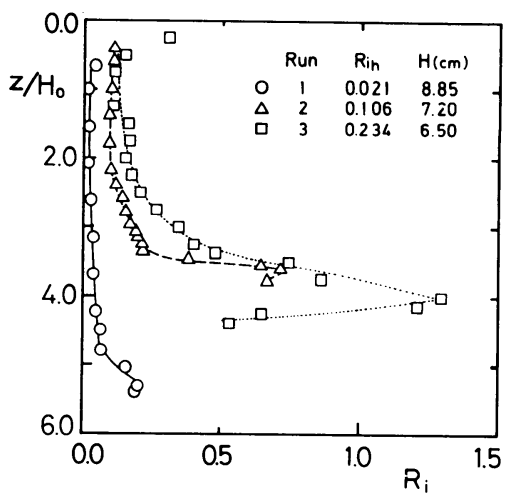

図一13 勾眍型リチャードソン数の鉛直方向分布 

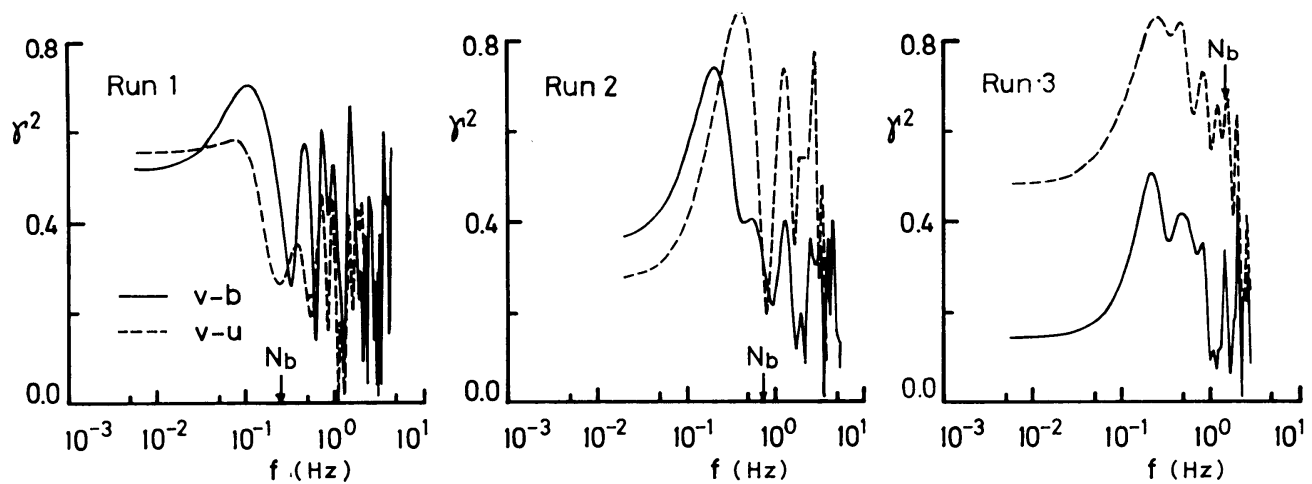

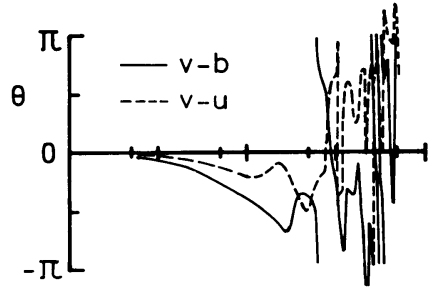

(a) $R i_{h}=0.021$ の場合

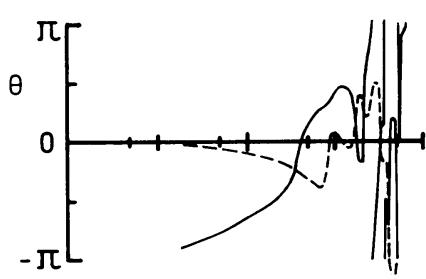

(b) $R i_{h}=0.016$ の場合

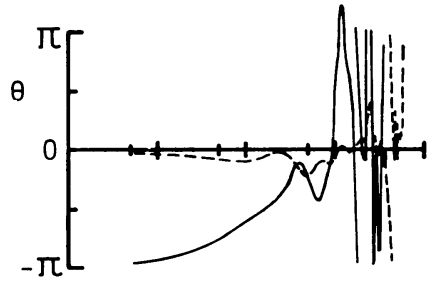

(c) $R i_{\text {s }}=0.234$ の場合

図-14 vとb, およびvとuのコヒーレンスと位相差

る.これに対して, 乱流の場合には位相差が 0 がにに 近づく.コヒーレンス $\gamma_{v b}^{2}$ と位相差 $\theta_{v b}$ はクロススペク トル $P_{v b}$ から周波数 $f$ の関数亡して次式のように求め られる。

$$
\left.\begin{array}{l}
\gamma_{v b}^{2}(f)=\left|P_{v b}(f)\right|^{2} / P_{v}(f) \cdot P_{b}(f) \\
\theta_{v b}(f)=\tan ^{-1}\left[Q_{v b}(f) / C_{v b}(f)\right]
\end{array}\right\}
$$

ここに， $Q_{v b}$ と $C_{v b}$ は $P_{v b}$ の虚部と実部であり， $P_{v}$, $P_{b}$ は $v, b$ 変動のパワースペクトルである， $\gamma_{v b}^{2}$ は各周 波数成分ごとの相関度を表わし， $\theta_{v b}$ はその位相差を示 す.

図-14 は各 Run の内部境界面での $v$ と, および $v$ と $u$ 変動間のコヒーレンスと位相差を周波数 $f$ に対し て示す. 図中の矢印は重力波の自由振動数の上限を表わ すブルント・バイサラ振動数 $N_{b}=[(g / \rho) \cdot d \rho / d z]^{1 / 2}=$ $[-\partial B / \partial z]^{1 / 2}$ を示す.

各 Run ともに, $f<N_{b}$ の範囲で $v-b$ 間のコヒーレン スの大きくなる周波数では位相差 $\theta_{v b}$ はほぼー $\pi / 2$ であ り, いずれの Runにおいても内部境界面は波状運動を 呈していることが予想される.

浮力分布から推算される Run 1 でのブルント・バイ サラ振動数 $N_{b}$ は $0.24 \mathrm{~Hz}$ であり，コヒーレンスの大き くなる周波数とは対応していない. また， $f>N_{b}$ の高 周波数側においても $\theta_{v b}=0, \pm \pi$ となるコヒーレンスの 大きい周波数成分が多数あり，Run $1\left(R i_{h}=0.021\right)$ で は乱流と内部波とが共存していることを暗示している.

これに対して, Run 3 $\left(R i_{h}=0.234\right)$ では $N_{b}=1.6$
$\mathrm{Hz}$ で明瞭なコヒーレンスのピークが認められるのをは じめとして $f<N_{b}$ でのコヒーレンスのピーク周波数 がそれぞれブルント・バイサラ振動数の $1 / 2,1 / 4,1 / 8$ 倍周波数に対応している. さらに， $f>N_{b}$ の高周波数 側でのコヒーレンスが小さいことから，Run 3 での内部 境界面は相当安定した成層状態にあり, 内部波が生起し ていることがわかる.

また，比較のために $v$ とのコヒーレンスと位相差 を同図に破線で示した。 Run 3 での $v-u$ 間のコヒーレ ンスは比較的大きいものの, その位相差はほぼ 0 となる. この傾向は $v-b$ 間の関係とは対照的である.つまり, $R i_{h}>0.12$ である Run 3 の内部境界面の挙動はブルン ト・バイサラ振動を基調とした内部波の波状運動を呈し ており,鉛直方向の運動量輸送を伴わないことがわかる.

\section{4. 結 語}

二次元表層密度噴流の遷移過程における乱流現象の理 解を目的に，せん断層リチャードソン数の異なる 4 断面 で乱流統計量の鉛直方向分布を測定し，乱流構造に及ぼ す浮力効果を実験的に解明した。. 本研究で得られた主要 な結果は以下のとおりである.

（1）乱流諸量の分布は浮力により強く影響される. それらのせん断層リチャードソン数 $R i_{h}$ に対する変化 は輸送方程式中に含まれる生成項の変化を考慮すること によって説明された。

（2）浮力変動にかかわる乱流諸量の分布特性ならび 
に浮力変動収支は $R i_{h} \doteqdot 0.12$ を境に著しく異なる.つ まり, $R i_{h}$ の増大とともに, 浮力変動は受動的な挙動か ら能動的な挙動へと遷移する．ことに，その遷移過程に ある $R i_{h}=0.106$ の断面では, 鉛直方向乱流浮力流束 $-\overline{v b}$ が正值となり, $v-b$ 変動間の相関係数が極端に減 少する特異な流れを呈する.

（3） $R i_{h}$ による乱流諸量の分布の差異は直接的には レイノルズ応力 $-\overline{u v}$ と $-\overline{v b}$ の違いに原因するが, 輸 送方程式の関連からいえば, その根源は平均流速と平均 浮力の鈶直方向分布の凹凸の相違にある．このことはひ いては周囲流体を連行するか否かに関係しており，文献 9)，10）で述べたせん断乱流特有の大規模組織構造が浮 力効果により崩壊するかどうかに深くかかわっている.

(4) $R i_{h}$ の小さな成層せん断流の内部境界面近傍の 領域では, 流速変動亡浮力変動の時系列に大振幅の正の 变動が間欠的に生じており, 乱流・非乱流界面に特有の 現象を呈する，浮力効果が増大するにつれ，この間欠的 な大スケールの乱流運動は成層化により抑圧されて崩壊 する. この結果として, 高波数側における乱流エネルギ 一の分担が増加する.このように, 浮力は乱れ変動のス ケールの減少をもたらし，鉛直方向の流体運動を抑圧す るとともに, 乱れ強度も減少させる.

（5） また， $R i_{h}=0.12$ は勾配型リチャードソン数で 表示される内部境界面の局所的安定条件 $\left(R i_{h} \$ 1.0\right)$ に対応していることが明らかになった。

（6）鉛直方向流速変動と浮力変動間の周波数別相関 性を検討した結果, ブルント・バイサラ振動数以下の低 周波数領域でコヒーレンスの大きくなる周波数では, 成 層度の大小にかかわらず位相差がほぼー $\pi / 2$ であるこ とがわかった。このことより，成層せん断流の内部境界 面では, 内部波が $R i_{h}$ の值に無関係に生起しているこ とが予想される.

最後に，実験ならびにデー夕解析に協力頂いた大阪大 学学生 角谷孝義氏 (現・関西電力(株) 勤務), 礒峷正哉 氏と浅田浩章氏に感謝の意を表します。

\section{参考文 献}

1) Kondo, J., Kanechika, O. and Yasuda, N. : Heat and Momentum Transfers under Strong Stability in the Atmospheric Surface Layer, J. Atmos. Sci., Vol. 35, pp. 1012 1021, 1978.

2）小森 悟-植田洋匡・荻野文丸・水科篤郎：安定成層流 の乱流構造, 国立公害研究所研究報告, 第 17 号, pp. 13 $\sim 48,1980$.

3) Ellison, T. H. : Turbulent Transfer of Heat and Momen- tum from a Finite Rough Plate, J. Fluid Mech., Vol.2, pp. 456 466, 1957.

4) Townsend, A. A. : Turbulent Flow in a Stably Stratified Atmosphere, J. Fluid Mech., Vol.5, pp. 361 372, 1958.

5) Gartrell, G. Jr. : Vertical Flux Measurements in a Density-Stratified Shear Flow, 2nd Inter. Sympo. on Stratified Flows, pp. 301 314, 1980.

6) Monin, A.S. and Obukhov, A.M. : Basic Laws of Turbulent Mixing in the Atmosphere near the Ground, Acad. Sci. USSR Leningrad Geophys. Inst., Vol. 24, pp. 163 187, 1954.

7) Launder, B. E. : On the Effects of a Gravitational Field on the Turbulent Transport of Heat and Momentum, J. Fluid Mech., Vol.67, pp. 569 581, 1975.

8) Yamada, T. : The Critical Richardson Number and the Ratio of the Eddy Transport Coefficient Obtained from a Turbulent Closure Model, J. Atmos. Sci., Vol. 32, pp. 926 933, 1975.

9）室田 明・中辻啓二・數内生死：二次元表層密度噴流に おける大規模渦運動に関する実験的研究，土木学会論文 報告集，第 339 号, pp. 109 118, 1983.

10）室田 明・中辻啓二・戸上拓也：二次元表層密度噴流の 初期発達過程に及ぼす成層効果について, 土木学会論文 報告集，第 342 号, pp. 115 123，1984.

11）室田 明・中辻啓二：二次元表層密度噴流における連行 特性に関する研究，土木学会論文集，第 351 号/ II -2, pp. 97 106, 1984.

12) Koop, C.G. and Browand, F. K. : Instability and Turbulence in a Stratified Fluid with Shear, J. Fluid Mech., Vol. 93, pp. 135 159, 1979.

13) Bradbury, L. J. S. : The Structure of a Self-preserving Turbulent Plane Jet, J. Fluid Mech., Vol.23, pp. 31 $64,1965$.

14) Gutmark, E. and Wygnanski, I. : The Planar Turbulent Jet, J. Fluid Mech., Vol.93, pp. 465 495, 1976.

15) Ramaprian, B. R. and Chandrasekhara, M. S. : Study of Vertical Plane Turbulent Jets and Plumes, Iowa Inst. of Hydro. Res., The Univ. of Iowa, IIHR Rept. No. 257, 402p. , 1983.

16) Monin, A.S. and Yaglom, A.M. : Statistical Fluid Mechanics, MIT Press, 1975.

17) Townsend, A. A. : The Structure of Turbulent Shear Flow, Cambridge Univ. Press, 429 p., 1956.

18) Taylor, G. I. : Effect of Variations of Density on the Stability of Superposed Streams of Fluid, Proc. Roy. Soc., Lond., Vol. A 132, pp. 499 523, 1931.

19) Stewart, R.W. : Turbulence and Waves in a Stratified Atmosphere, Radio Soci., Vol.4, No.12, pp.1269 1278, 1969.

(1984.2.16 - 受付) 